\title{
Non-cystic fibrosis bronchiectasis: review and recent advances
}

\author{
Galit Livnat and Lea Bentur*
}

\author{
Address: Meyer Children's Hospital, Rambam Medical Center, Haifa 31092, Israel \\ * Corresponding author: Lea Bentur (1_bentur@rambam.health.gov.il) \\ FI000 Medicine Reports 2009, I:67 (doi:10.3410/MI-67) \\ The electronic version of this article is the complete one and can be found at: http:/FI000.com/Reports/Medicine/content/I/67
}

\begin{abstract}
Bronchiectasis is an abnormal dilatation of bronchi and bronchioles associated with repeated cycles of airway infection and inflammation. This review will focus on non-cystic fibrosis bronchiectasis in children, with regard to etiology, diagnosis, treatment options, and recent advances.
\end{abstract}

\section{Introduction and context}

Although the frequency of childhood bronchiectasis has been reduced in western countries, it remains a common problem in poorer countries and among certain demographic groups (native Alaskan children in the USA, in Pacific Islanders, and in New Zealand Maori). Additionally, non-cystic fibrosis (non-CF) bronchiectasis is now being identified more often by high resolution computed tomography (CT).

Bronchiectasis results when inflammatory and infectious damage to the bronchial and bronchiolar walls leads to a vicious cycle of airway injury [1] and airway and lung parenchyma destruction [2]. Sputum analyses and bronchial mucosal biopsy specimens from bronchiectasis patients have shown increased concentrations of elastase [3], interleukin-8 [4], tumor necrosis factor [5], and prostanoids [6]. Hence, anatomic factors, chronic infection and inflammation, and host defense all play important, yet poorly understood, roles in the development of bronchiectasis [7].

Bronchiectasis is categorized as focal or diffuse. All patients with focal bronchiectasis require bronchoscopy and/or high resolution CT to evaluate the airways, while patients with diffuse bronchiectasis should be assessed for underlying systemic abnormalities. Focal bronchiectasis can be secondary to airway obstruction such as bronchial atresia/malacia/stenosis, vascular ring/sling, following foreign body aspiration, extrinsic compression, airway tumors, necrotizing pneumonia, or congenital parenchymal malformation. The etiologies of diffuse non-CF bronchiectasis are presented in Table 1. Even after thorough evaluation, diagnosis remains idiopathic in the majority of patients. The relative frequency of each etiology varies, but idiopathic, post-infectious, and immune deficiencies are probably the commonest etiologies.

\section{Diagnosis and treatment}

Bronchiectasis should be suspected in children who present with chronic productive cough, airway obstruction, and recurrent infections. The diagnosis is made by high-resolution CT scans, which can classify the bronchiectasis as focal or diffuse, cylindrical, varicose, or saccular.

Treatment goals are to reduce the number of exacerbations and improve quality of life. Therapeutic strategies are largely derived from CF. All patients with bronchiectasis should have a microbiological examination (spontaneous/induced sputum or bronchoalveolar lavage) for routine bacterial and non-tuberculosis mycobacteria (NTM). About one-third of patients with non-CF bronchiectasis are chronically colonized with Pseudomonas aeruginosa. Patients with $P$. aeruginosa experience an accelerated decline in lung function and more frequent exacerbations [8]. Maintenance therapy with inhaled tobramycin has shown a microbiological benefit in two studies $[1,9]$ but those studies were not powered to detect a clinical benefit. Antimicrobial, antiinflammatory, airway clearance therapies, and immunization are the mainstays of therapy. 
Table I. Etiologies of non-cystic fibrosis bronchiectasis

\begin{tabular}{|c|c|c|}
\hline Etiology & Examples & Comments \\
\hline Idiopathic & & Should be classified after a thorough evaluation \\
\hline Post-infection & Post measles, pertussis, adenovirus, tuberculosis & $\begin{array}{l}\text { Decreasing frequency in western countries. Non- } \\
\text { progressive bronchiectasis }\end{array}$ \\
\hline Genetic disease & $\begin{array}{l}\text { CF, primary ciliary dyskenesia*, alfa I anti-trypsin (AAT) } \\
\text { deficiency }\end{array}$ & $\begin{array}{l}\text { Atypical CF has been increasingly recognized. AAT } \\
\text { causes bronchiectasis only in adulthood }\end{array}$ \\
\hline Aspiration/gastroesophageal reflux & $\begin{array}{l}\text { Impaired gag reflex, impaired esophageal motility, } \\
\text { esophageal atresia + fistula, convulsions, cleft palate }\end{array}$ & $\begin{array}{l}\text { Barium swallow, } \mathrm{pH} \text { metry, and swallowing mechanisms } \\
\text { should be evaluated }\end{array}$ \\
\hline Immune deficiency & $\begin{array}{l}\text { Severe combined immune deficiency, Omenn's syn- } \\
\text { drome, hypogammaglobulinemia, hyper-lgE chronic } \\
\text { granulomatous disease, common variable hypogamma*, } \\
\text { ataxia telangiectasia, bare lymphocyte syndrome*, } \\
\text { DELI*, Wiskott-Aldrich syndrome, HIV, immunosup- } \\
\text { pressive treatment [corticosteroids, irradiation, organ } \\
\text { and bone marrow transplants, biologic agents } \\
\text { (for example, infliximab, etanercept)] }\end{array}$ & $\begin{array}{l}\text { This group has increased due to descriptions of new } \\
\text { immune deficiencies and increased iatrogenic immuno- } \\
\text { deficiency. Refer for immunological evaluation }\end{array}$ \\
\hline Collagen vascular disorders & Systemic lupus erythematosus, rheumatoid arthritis & \\
\hline Inflammatory bowel diseases & Úlcerative colitis, Crohn's disease & \\
\hline Miscellaneous & $\begin{array}{l}\text { Sarcoidosis, Young syndrome, Mounier-Kuhn } \\
\text { syndrome, Ehler-Danlos syndrome, Marfan } \\
\text { syndrome, yellow nail syndrome }\end{array}$ & \\
\hline ABPA & $\mathrm{CF}$, asthma & New treatment options* \\
\hline
\end{tabular}

*See text for recent advances. AAT, alfa I anti-trypsin; ABPA, allergic bronchopulmonary aspergillosis; CF, cystic fibrosis; DEL-I, developmental endothelial locus-I.

\section{Recent advances Etiology}

Common variable immunodeficiency should be considered, as the age at diagnosis shows two peaks, between 6 and 10 years of age, and in young adulthood [10].

Bare lymphocyte syndrome is an autosomal recessive disorder [11] characterized by the absence of constitutive and inducible expression of major histocompatibility complex class II (MHCII) genes [12,13], which affect all cell types. An additional immune deficiency associated with pulmonary manifestations is that of Del-1 (developmental endothelial locus-1), which is an anti-adhesive factor that interferes with leukocyte-endothelial adhesion dependent on the integrin lymphocyte function-associated antigen-1 (LFA-1). Endothelial Del-1 deficiency increases LFA-1-dependent leukocyte adhesion and transmigration into the lungs, leading to excessive neutrophilic lung inflammation and bronchiectasis [14].

Post-infectious bronchiectasis secondary to NTM may occur in children with CF or HIV infection and in middle-aged Caucasian women without pre-existing conditions [15]. Of interest, in one study $36 \%$ of these females carried mutations in the CF transmembrane regulator (CFTR) gene [16].

\section{Diagnosis}

Primary ciliary diskenesia (PCD) is characterized by bronchiectasis, rhinosinusitis, ear infections, and infertility. Approximately one-half of the patients with PCD have situs inversus totalis or heterotaxy [17]. Eight genes have been linked with PCD: two outer dynein arm (ODA) genes, intermediate chain (DNAI1) and heavy chain (DNAH5), have been found to be mutated in approximately $30-38 \%$ of affected families [18-21]. Mutations in other ODA genes (TXNDC3 and DNAI2) have been noted in a small fraction (approximately 2\%) of PCD patients [22]. Lately, mutations in $k t u$, which is required for the dynein complex assembly, have been described in approximately $12 \%$ of PCD patients with defects in both the ODA and inner dynein arm (IDA) [23]. Recently, mutations in radial spoke head protein genes RSPH9 and RSPH4A have been shown to cause central-microtubular-pair abnormalities in seven consanguineous Pakistani families in the UK [24]. Digital high-speed videomicroscopy has been used to detect more subtle abnormalities in ciliary beat pattern and has demonstrated that some of these patterns are associated with specific ultrastructural defects: immotile or limited flickering for ODA defects; low-amplitude stiff beat for isolated IDA defects or radial spoke defects; and circular, whip-like beat for central microtubular defects such as transposition [25]. The nasal nitric oxide method was shown to be a bona fide diagnostic test, as in PCD nasal and exhaled nitric oxide values are lower than normal, for reasons that are still unclear [26].

\section{Treatment}

There is no evidence base or consensus on the treatment of non-CF bronchiectasis [27]. Anwar et al. [28] recently reported the efficacy of long-term, oral, low-dose 
azithromycin in non-CF bronchiectasis patients. Beneficial effects were demonstrated on exacerbation frequency, sputum microbiology, FEV1 (forced expiratory volume in 1 second) testing, and sputum volume. This therapy was recommended for the management of difficult-to-control bronchiectasis. The mechanism of action of azithromycin is not fully elucidated, but studies suggest potential immunomodulatory effects. Azithromycin significantly reduces bronchoalveolar lavage neutrophilia and interleukin-8 mRNA [29]. It is also known to have prokinetic effects on the gut and has been associated with lower levels of aspiration markers. The anti-pseudomonal effect of azithromycin may represent an inhibitory effect on quorum sensing (a phenomenon whereby the accumulation of signaling molecules enables a single cell to sense the number of bacteria according to the local density of their population), biofilm formation, production of immunostimulatory exoproducts, and the inflammatory response to this organism [30].

There is an ongoing debate about the efficacy of inhaled corticosteroids in CF and non-CF bronchiectasis [31]. Mucoactive agents such as hypertonic saline $7 \%$ are beneficial in patients with CF [32]. Few reports are available on hypertonic saline in non-CF bronchiectasis. Mannitol in a dry powder inhaler has been used as a hyperosmolar stimulus to increase mucociliary clearance in bronchiectatic subjects [33].

Two case reports documented the usefulness of shortterm use of dornase alfa in treating PCD [34]. As DNAH5 mutations in PCD patients are nonsense mutations, pharmacogenetic therapies such as PTC124 that are designed to read through premature stop codons may potentially correct the primary defect in these PCD patients.

Allergic bronchopulmonary aspergillosis (ABPA) treatment involves long-term attenuation of the inflammatory and immunological activity with corticosteroids and reduction of the antigen burden from fungal colonization with antifungal agents. High-dose intravenous pulse methylprednisolone was found to be an effective treatment for ABPA in $\mathrm{CF}$ with relatively minor side effects [35]. Omalizumab, a humanized monoclonal antibody directed against $\mathrm{IgE}$, has a potential role as adjuvant therapy for CF patients that are corticosteroiddependent [36].

\section{Prognosis}

Lung function usually stabilizes in children with non-CF bronchiectasis [27] if diagnosed early and a consequent long-term treatment plan is followed. Surgery and lung transplantation are rarely required for non-CF bronchiectasis.

\section{Implications for clinical practice}

Non-CF bronchiectasis in childhood is still a common cause of childhood morbidity. Identifying and treating the underlying disease is essential to prevent the progression of bronchiectasis. New diagnostic tools such as the nasal nitric oxide test, immunological tests for bare lymphocyte syndrome and DEL-1, and culture for NTM, may aid in specific diagnosis. Therapeutic strategies are largely derived from CF bronchiectasis and include antimicrobial, anti-inflammatory, and airway clearance therapies, and immunization. Pulse steroids and omalizumab may offer a better control for ABPA. Azithromycin, as an immuno-modulator agent, should be considered in patients with severe bronchiectasis. The role of new mucoactive agents should be further explored.

\section{Abbreviations}

ABPA, allergic bronchopulmonary aspergillosis; CF, cystic fibrosis; CFTR, CF transmembrane regulator; CT, computed tomography; Del-1, developmental endothelial locus-1; FEV1, forced expiratory volume in 1 second; IDA, inner dynein arm; LFA-1, lymphocyte functionassociated antigen-1; MHCII, major histocompatibility complex class II; NTM, non-tuberculous mycobacteria; ODA, outer dynein arm; PCD, primary ciliary diskenesia.

\section{Competing interests}

The authors declare that they have no competing interests.

\section{References}

I. Barker AF: Bronchiectasis. N Engl J Med 2002, 346:I383-93.

2. Cole PJ: Inflammation: a two-edged sword - the model of bronchiectasis. Eur J Respir Dis Suppl 1986, I47:6-I5.

3. Tsang KW, Chan K, Ho P, Zheng L, Ooi GC, Ho JC, Lam W: Sputum elastase in steady-state bronchiectasis. Chest 2000, I I 7:420-6.

4. Richman-Eisenstat JB, Jorens PG, Hébert CA, Ueki I, Nadel JA: Interleukin-8: an important chemoattractant in sputum of patients with chronic inflammatory airway diseases. Am J Physiol 1993, 264:L4I3-8.

5. Shum DK, Chan SC, Ip MS: Neutrophil-mediated degradation of lung proteoglycans: stimulation by tumor necrosis factoralpha in sputum of patients with bronchiectasis. Am J Respir Crit Care Med 2000, 162:1925-31.

6. Tamaoki J, Chiyotani A, Kobayashi K, Sakai N, Kanemura T, Takizawa T: Effect of indomethacin on bronchorrhea in patients with chronic bronchitis, diffuse panbronchiolitis, or bronchiectasis. Am Rev Respir Dis 1992, I45:548-52.

7. Fuschillo S, De Felice A, Balzano G: Mucosal inflammation in idiopathic bronchiectasis: cellular and molecular mechanisms. Eur Respir J 2008, 31:396-406.

8. Martínez-García MA, Soler-Cataluña JJ, Perpiñá-Tordera M, RománSánchez $\mathrm{P}$, Soriano J: Factors associated with lung function decline in adult patients with stable non-cystic fibrosis bronchiectasis. Chest 2007, I32:1565-72. 
9. Scheinberg P, Shore E: A pilot study of the safety and efficacy of tobramycin solution for inhalation in patients with severe bronchiectasis. Chest 2005, 127:1420-6.

10. Urschel S, Kayikci L, Wintergerst U, Notheis G, Jansson A, Belohradsky $\mathrm{BH}$ : Common variable immunodeficiency disorders in children: delayed diagnosis despite typical clinical presentation. J Pediatr 2009, 154:888-94.

II. Lisowska-Grospierre B, Fondaneche MC, Rols MP, Griscelli C, Fischer A: Two complementation groups account for most cases of inherited MHC class II deficiency. Hum Mol Genet I994, 3:953-8.

12. Klein C, Lisowska-Grospierre B, LeDeist F, Fischer A, Griscelli C: Major histocompatibility complex class II deficiency: clinical manifestations, immunologic features, and outcome. J Pediatr 1993, | 23:92|-8.

13. Elhasid R, Etzioni A: Major histocompatibility complex class II deficiency: a clinical review. Blood Rev 1996, 10:242-8.

14. Choi EY, Chavakis E, Czabanka MA, Langer HF, Fraemohs L, Economopoulou M, Kundu RK, Orlandi A, Zheng YY, Prieto DA, Ballantyne CM, Constant SL, Aird WC, Papayannopoulou T, Gahmberg CG, Udey MC, Vajkoczy P, Quertermous T, Dimmeler S, Weber C, Chavakis T: Del-I, an endogenous leukocyte-endothelial adhesion inhibitor, limits inflammatory cell recruitment. Science 2008, 322:I I0I-4.

FI000 Factor 3.0 Recommended

Evaluated by Caroline Owen 05 Jan 2009

15. Kim RD, Greenberg DE, Ehrmantraut ME, Guide SV, Ding L, Shea Y, Brown MR, Chernick M, Steagall WK, Glasgow CG, Lin J, Jolley C, Sorbara L, Raffeld M, Hill S, Avila N, Sachdev V, Barnhart LA, Anderson VL, Claypool R, Hilligoss DM, Garofalo M, Fitzgerald A, Anaya-O'Brien S, Darnell D, DeCastro R, Menning HM, Ricklefs SM, Porcella SF, Olivier KN, et al.: Pulmonary nontuberculous mycobacterial disease: prospective study of a distinct preexisting syndrome. Am J Respir Crit Care Med 2008, 178: 1066-74.

FI000 Factor 3.0 Recommended

Evaluated by Shawn Skerrett 16 Dec 2008

16. Ziedalski TM, Kao PN, Henig NR, Jacobs SS, Ruoss SJ: Prospective analysis of cystic fibrosis transmembrane regulator mutations in adults with bronchiectasis or pulmonary nontuberculous mycobacterial infection. Chest 2006, 130:995-1002.

17. Kennedy MP, Noone PG, Leigh MW, Zariwala MA, Minnix SL, Knowles MR, Molina PL: High-resolution CT of patients with primary ciliary dyskinesia. AJR Am J Roentgenol 2007, 188: I232-8.

18. Failly M, Saitta A, Muñoz A, Falconnet E, Rossier C, Santamaria F, de Santi MM, Lazor R, DeLozier-Blanchet CD, Bartoloni L, Blouin JL: DNAII mutations explain only $2 \%$ of primary ciliary dykinesia. Respiration 2008, 76:198-204.

19. Guichard C, Harricane MC, Lafitte JJ, Godard P, Zaegel M, Tack V, Lalau G, Bouvagnet P: Axonemal dynein intermediate-chain gene (DNAII) mutations result in situs inversus and primary ciliary dyskinesia (Kartagener syndrome). Am J Hum Genet 200 I, 68:1030-5.

20. Hornef N, Olbrich H, Horvath J, Zariwala MA, Fliegauf M, Loges NT, Wildhaber J, Noone PG, Kennedy M, Antonarakis SE, Blouin JL, Bartoloni L, Nüsslein T, Ahrens P, Griese M, Kuhl H, Sudbrak R, Knowles MR, Reinhardt R, Omran H: DNAH5 mutations are a common cause of primary ciliary dyskinesia with outer dynein arm defects. Am J Respir Crit Care Med 2006, 174:120-6.

21. Zariwala MA, Leigh MW, Ceppa F, Kennedy MP, Noone PG, Carson JL, Hazucha MJ, Lori A, Horvath J, Olbrich $H$, Loges NT, Bridoux AM, Pennarun G, Duriez B, Escudier E, Mitchison HM, Chodhari R, Chung EM, Morgan LC, de longh RU, Rutland J, Pradal U, Omran $\mathrm{H}$, Amselem S, Knowles MR: Mutations of DNAII in primary ciliary dyskinesia: evidence of founder effect in a common mutation. Am J Respir Crit Care Med 2006, 174:858-66.
22. Loges NT, Olbrich H, Fenske L, Mussaffi H, Horvath J, Fliegauf M, Kuhl H, Baktai G, Peterffy E, Chodhari R, Chung EM, Rutman A, O'Callaghan C, Blau H, Tiszlavicz L, Voelkel K, Witt M, Zietkiewicz E, Neesen J, Reinhardt R, Mitchison HM, Omran H: DNAl2 mutations cause primary ciliary dyskinesia with defects in the outer dynein arm. Am J Hum Genet 2008, 83:547-58.

23. Omran $H$, Kobayashi D, Olbrich H, Tsukahara T, Loges NT, Hagiwara H, Zhang Q, Leblond G, O'Toole E, Hara C, Mizuno H, Kawano H, Fliegauf M, Yagi T, Koshida S, Miyawaki A, Zentgraf H, Seithe H, Reinhardt R, Watanabe Y, Kamiya R, Mitchell DR, Takeda H: Ktu/PFI 3 is required for cytoplasmic pre-assembly of axonemal dyneins. Nature 2008, 456:6 II-6.

FI000 Factor 4.9 Must Read

Evaluated by Trina Schroer 08 Jan 2009, Greg Pazour 30 Jan 2009 , Herbert Steinbeisser 03 Apr 2009

24. Castleman VH, Romio L, Chodhari R, Hirst RA, de Castro SC, Parker KA, Ybot-Gonzalez P, Emes RD, Wilson SW, Wallis C, Johnson CA, Herrera RJ, Rutman A, Dixon M, Shoemark A, Bush A, Hogg C, Gardiner RM, Reish O, Greene ND, O'Callaghan C, Purton S, Chung EM, Mitchison HM: Mutations in radial spoke head protein genes RSPH9 and RSPH4A cause primary ciliary dyskinesia with central-microtubular-pair abnormalities. Am J Hum Genet 2009, 84:197-209.

25. Chilvers MA, Rutman A, O'Callaghan C: Ciliary beat pattern is associated with specific ultrastructural defects in primary ciliary dyskinesia. J Allergy Clin Immunol 2003, I I 2:5 I8-24.

26. Narang I, Ersu R, Wilson NM, Bush A: Nitric oxide in chronic airway inflammation in children: diagnostic use and pathophysiological significance. Thorax 2002, 57:586-9.

27. Bastardo CM, Sonnappa S, Stanojevic S, Navarro A, Lopez PM, Jaffe A, Bush A: Non-cystic fibrosis bronchiectasis in childhood: longitudinal growth and lung function. Thorax 2009, 64:246-5I.

28. Anwar GA, Bourke SC, Afolabi G, Middleton P, Ward C, Rutherford RM: Effects of long-term low-dose azithromycin in patients with non-CF bronchiectasis. Respir Med 2008, 102:1494-6.

FI000 Factor 3.0 Recommended Evaluated by Cori Daines 30 Oct 2008

29. Verleden GM, Vanaudenaerde BM, Dupont LJ, Van Raemdonck DE: Azithromycin reduces airway neutrophilia and interleukin-8 in patients with bronchiolitis obliterans syndrome. Am J Respir Crit Care Med 2006, I74:566-70.

30. Mertens V, Blondeau K, Pauwels A, Farre R, Vanaudenaerde B, Vos R, Verleden G, Van Raemdonck DE, Dupont LJ, Sifrim D: Azithromycin reduces gastroesophageal reflux and aspiration in lung transplant recipients. Dig Dis Sci 2009, 54:972-9.

31. Kapur N, Bell S, Kolbe J, Chang AB: Inhaled steroids for bronchiectasis. Cochrane Database Syst Rev 2009:CD000996.

32. Wark P, McDonald VM: Nebulised hypertonic saline for cystic fibrosis. Cochrane Database Syst Rev 2009:CD00I506.

33. Ilowite J, Spiegler P, Chawla S: Bronchiectasis: new findings in the pathogenesis and treatment of this disease. Curr Opin Infect Dis 2008, 21:163-7.

34. ten Berge M, Brinkhorst G, Kroon AA, de Jongste JC: DNase treatment in primary ciliary dyskinesia - assessment by nocturnal pulse oximetry. Pediatr Pulmonol 1999, 27:59-6I.

35. Cohen-Cymberknoh M, Blau H, Shoseyov D, Mei-Zahav M, Efrati O, Armoni S, Kerem E: Intravenous monthly pulse methylprednisolone treatment for ABPA in patients with cystic fibrosis. J Cyst Fibros 2009, 8:253-7.

36. Zirbes JM, Milla CE: Steroid-sparing effect of omalizumab for allergic bronchopulmonary aspergillosis and cystic fibrosis. Pediatr Pulmonol 2008, 43:607-10. 